\title{
Gelişmekte Olan Ülkelerde Sermaye İthali - Yurtiçi Tasarruf ve Ekonomik Büyüme İlişkisi: Türkiye Üzerine Ampirik Bir Uygulama
}

\author{
Zeki KARTAL, Hakan ACAROĞLU*
}

\begin{abstract}
Gelişmekte Olan Ülkelerde Sermaye İthali - Yurtiçi Tasarruf ve Ekonomik Büyüme İlişkisi: Türkiye Üzerine Ampirik Bir İnceleme

Özet

Bu çalışmada "Sermaye ithali Türkiye'de yurtiçi tasarrufu ve ekonomik büyümeyi etkin kılmakta mıdır?" sorusuna cevap aranmaktadır. Çalışmanın amacını, iki farklı kalkınma stratejisi döneminde (ithal ikameci 1964-1980 ve ihracata yönelik 19802012) ve bütün olarak her iki dönemi kapsayan 1964-2012 yılları arasında Türkiye'de ekonomik büyüme, yurt içi tasarruf ve sermaye ithali arasındaki ilişkileri göstermek oluşturmuştur. Bunu gerçekleştirmek için uygulanan yöntemde Grangernedensellik teknikleri kullanılmaktadır. 1964-1980 döneminde değişkenler arasında çift yönlü bir nedensellik ilişkisi keşfedilirken 1980-2012 ile 1964-2012 dönemlerinde bir nedensellik gözlemlenmemiştir. Buradan hareketle, gelişmekte olan bir ülke konumundaki Türkiye'nin kamu ve özel sektör borçlarının toplamı olan sermaye ithalinin yurtiçi tasarruf ve ekonomik büyümeye etkisinin uygulanan kalkınma stratejilerine göre farkllıklar gösterip, dönemler itibariyle istikrarsız bir seyir izlediği anlaşılmaktadır.
\end{abstract}

Anahtar Kelimeler: Sermaye ithali, Dış Borç, Yurtiçi Tasarruf, Ekonomik Büyüme, Zaman Serisi Analizi
The Relationship of Capital Import - Domestic Saving and Economic Growth in Developing Countries: An Empirical Application on Turkey

Abstract

In this study, an answer is looked for the question of "Does capital import activate domestic saving and economic growth in Turkey?". Displaying the relationships between economic growth, domestic saving and capital import has formed the purpose of the study in two different development strategy period (import substitution period; 1964-1980 and exportoriented period; 1964-2012) and covering both two period; 1964-2012. Granger-causality techniques are used to perform this in applied methodology. While the bi-directional causality between variables has been investigated in the period 19641980 , the causality has not been observed in the period 19802012 and 1964-2012. It is understood from this point of view that, the effects of capital import which is the sum of public and private sectors to domestic saving and economic growth for Turkey that has position of developing country shows differences according to applied development strategies, and this effect follows an unstable path.

Key Words: Capital Import, Foreign Depth, Domestic Saving, Economic Growth, Time Series Analysis

\section{Giriş}

Sermaye ithalinin (kamu ve özel kesimin yabancı ülke ve finans kuruluşlarından aldığı borçların toplamı) gelişmekte olan ülkelerde ekonomik büyümeye ve iç tasarrufa etkisi tartışmalı bulunmak-

* Zeki KARTAL, Doç. Dr., Eskişehir Osmangazi Üniversitesi, ỉktisadi ve İdari Bilimler Fakültesi, ìktisat Bölümü, zkartal@ogu.edu.tr; Hakan ACAROĞLU, Yrd. Doç. Dr., Eskişehir Osmangazi Üniversitesi, ỉktisadi ve İdari Bilimler Fakültesi, İktisat Bölümü, hacaroglu@ogu.edu.tr 


\section{Zeki KARTAL | Hakan ACAROĞLU}

tadır. Rosenstein-Rodan (1961), Chenery ve Strout (1966) gibi yazarlar gelişmekte olan ülkelerde sermaye ithalinin ekonomik büyümeye ve iç tasarrufa yol açabileceği tezini ileri sürerken Bigler (1987), Agarwal ve diğerleri (1984) gibi yazarlar da sermaye ithalinin bu ülkelerde ekonomik gelişmeyi ve iç tasarrufu hızlandırmadığı tezini ileri sürmektedirler. Bu çalışma, Türkiye örneğinde yukarıdaki tezlerden hangisinin anlamlı olduğunu belirlemeyi amaçlamaktadır. Bunu, ithal ikameci kalkınma stratejisi döneminde 1964-1980 arası ve ihracata yönelik kalkınma stratejisi döneminde 1980-2012 arası yıllarda yapılan toplam sermaye ithalinin (kamu ve özel sektörün kısa-orta-uzun vadede) Granger-nedensellik teknikleri yardımıyla ve bunların sonuçlarına dayanarak ortaya koymaktadır. Buradan hareketle araştırmanın temel problemini "Sermaye ithali Türkiye'de yurtiçi tasarrufu ve ekonomik büyümeyi etkin kılmakta mıdır?" sorusu oluşturmaktadır.

\section{Gelişmekte Olan Ülkelerde Genel Gelişme Hedefi Olarak Sanayileşme}

Modernleşme ve sanayileşme, gelişme politikalarının stratejik bir tasarımı olarak ve "modernleşme teorilerine" göre de küresel çerçevede gerçekleştirilebilir görülmektedir. Buna karşın "bağımlılık (dependence) teorileri” kapitalist dünya sisteminin pazar ve güç ilişkilerinden dolayı bunu gerçekleştirilemez bir proje olarak görmektedir. Sürekli olarak yapısı ve dinamiği geçtiğimiz yüzyıllarda Avrupa'nın ve Kuzey Amerika'nın gelişmiş toplumlarında ortaya çıkan toplumsal bir düzen referans olarak alınmaktadır: Modern kapitalist dünya toplumu kendi gelişmesini bizzat birbirini izleyen aşamalardan geçerek tamamladı ve 20. yüzyılın sonunda ortaya fordist veya post-fordist aşama olarak tanımlanan bir resim konuldu. Dünya çapında gelişmenin standardı işte bu resimden alınmış bulunmaktadır (Altvater, 1993, s.398).

Gelişmekte olan ülkelerin sanayileşmeleri ve sanayi sektörlerinin gelişmiş sanayi ülkeler örneğine göre "uluslararası işbölümüne" entegrasyonu oldum olası önemli bir ekonomik meydan okuma olarak görülmektedir. Gelişmekte olan ülkelerde sanayileşmenin, ekonomik krizlerden doğan problemleri ve artan işsizliği pozitif etkilemesi beklenmekteydi: Prensip olarak bir taraftan çeşitlendirilmiş ekonomi sayesinde gelişmekte olan ülkelerin dünya pazarındaki konjonktürel dalgalanmalarından daha az etkilenmesi sanayileşme stratejisinin lehine olan bir gerçeklik olarak görülmektedir. Diğer yandan oluşan yerli sanayi iş piyasasına yeni gelen iş gücünü kabul ederek tarımdaki fazla ve üretken olmayan iş gücünü absorbe edebilir bulunmaktadır (Knall ve Wagner, 1986, s.75).

Fakat "uluslararası iş bölümünün" başka bir yapıya sahip olduğu gözlenmektedir. Birçok gelişmekte olan ülke tarımsal ve madensel hammadde ihracatçısı aynı zamanda da sanayi malları ithalatçısı olarak tamamen ya da büyük ölçüde "tamamlayıcı uluslararası işbölümü" aşamasında bulunmaktadır. Yukarıdaki değerlendirmeye göre ve bundan dolayı hammadde ihraç eden ülkeler (bunlar sanayi ürünleri ihracatçısı olmak için çaba harcamamaktadırlar veya harcayıp ta olamamaktadırlar), belki de yukarıda bahsedilen gelişme şansını kaçırmaktadırlar (Glismann ve diğerleri, 1987, s. 131).

Zaman içerisinde gelişme politikası ile ulaşılmak istenen hedefte bir dönüşüm yaşandı. Ancak buna rağmen, bugün hemen hemen tüm gelişmekte olan ülkelerin sanayileşmeye öncelik verdiği tespit edilmektedir. Bu durum kendisini artan sanayi üretiminde de göstermektedir. Zaten geçmiş- 
te gelişmekte olan ülkelerde her durumda mamul ürünler, açık bir şekilde sanayi ülkelerinkinden daha hızlı artmış bulunmaktadır. Sanayi ülkelerinde son on yılın yavaş büyümesi aşıımak istense de sanayi ülkelerinin büyüme hızı ile gelişmekte olan ülkelerin büyüme hızı arasında hatırı sayılır bir mesafe bulunmaktadır. Bu kendisini öncelikle dünya sanayi ürünlerinde gelişmekte olan ülkelerin payının zayıf bir kaymasında ifade etmektedir, çünkü gelişmekte olan ülkelerin ağırlığı henüz çok az düzeyde hissedilmektedir. Buradan hareketle, gelişmekte olan ülkelerin dünya sanayi üretimindeki payı 2000 yılına kadar \%20'nin altında kalabilir ön görüsünde bulunulmaktadır (Glismann ve diğerleri, 1987, s.39). Glismann ve diğerlerinin öngörülerinin doğruluğu Birleşmiş Milletler Endüstriyel Kalkınma Organizasyonu'nun (UNIDO) yayınlamış olduğu raporda da görülmektedir (UNIDO, 2013, s.171). Diğer taraftan sanayileşme alanındaki başarının ülkeden ülkeye çok farklı olduğu ve ortalama rakamların başarıyı yansıtmadığı dikkatleri çekmektedir. Sanayileşme sayesinde ekonomik büyüme ile gelişmekte olan ülkelerde yoksulluğun bertaraf edilmesi istenmektedir. Fakat ekonomik büyümeye rağmen yoksulluk ortadan kaldırılamamakta ve problem devam etmektedir.

20. yüzyılın başlarında bazı Latin Amerika ülkelerinde sanayileşme başlamıştır. 1930'lu yıllardaki dünya ekonomik krizi Arjantin, Brezilya, Meksika, Şili, Uruguay ve Kolombiya'da 20. yüzyılın başlarında başlanan sanayinin devam etmesini hızlandırdı. Latin Amerika'nın diğer ülkelerinde sanayileşme ilk defa 1930'lu yıllarda ve her şeyden önce İkinci Dünya Savaşı sırasında başladı (Guldimann, 1975, s.113). Gelişmekte olan ülkelerde sanayileşmenin ikinci itişi 1960'lı ve 1970'li yıllarda gerçekleşti. 1960'।ı ve 1970'li yıllarda birçok gelişmekte olan ülkelerde çok hızı bir sanayi gelişmesi yaşandı. İmalat sanayisinin gelişme oranı bu gelişmeyi takip eden şekliyle yansıtmaktadır: 1960'tan 1970'e kadar UNCTAD’ın (Birleşmiş Milletler Ticaret ve Kalkınma Örgütü) verilerine göre gelişmekte olan ülkelerdeki imalat sanayisi yıllık ortalama \%6,4, hatta 1970-1976 arası \%7,5 büyüme oranı kaydetmektedir. Batılı sanayi ülkelerinde aynı zaman dilimleri içerisinde büyüme oranı \%5,8 ve \%3,4 olarak gerçekleşmektedir (UNCTAD, 1979, s.534). Türkiye için bu oran (bkz. Dünya Kalkınma Göstergeleri) dünya kalkınma göstergelerinden elde edilen veriler ile $\% 8,4$ olarak hesaplanmıştır (hesaplama yazarların kendisine aittir).

Birçok gelişmekte olan ülkede bu gün sanayileşme politikası krizde bulunmaktadır: Mamul mal fiyatlarıyla ham madde fiyatlarını karşılaştırdığımızda bu ülkeler dünya piyasasında ithal ettikleri sermaye mallarını pahalı alırken ihraç ettikleri ham maddeleri ucuza satmaktadırlar. Sanayi ülkelerinde hammaddeleri diğer ürünlerle ikame etme eğilimi oluşmaktadır. Yeni teknolojide hammaddelerin payı sürekli azalmaktadır. Sanayi ülkelerinin gelişmekte olan ülkelerden tüketim maddelerine olan talebi sınırlı kalırken, gelişmekte olan ülkelerin kendi sanayileşmeleri için gerekli gördükleri sermaye ürünlerine olan talebi sürekli artmaktadır (Kreye, 1980, s.286). Uluslararası pazarlar büyük ölçüde sanayi ülkelerindeki firmalar tarafından kontrol edilmektedir. Buradan hareketle sanayi ülkelerinde ulaşılmış olan yaşam standardına hammadde ihraç eden ülkelerin de katkısı bulunduğu da söylenmektedir.

Aşağıda, özellikle geleneksel iktisada dayalı Ortodoks gelişme teorilerinin ekonomist bir bakış açısıyla dillendirdiği, gelişmekte olan ülkelerin dış kaynaklarla sanayileşebileceği tezi kısaca açılmaya çalışılmaktadır. 


\section{Zeki KARTAL | Hakan ACAROĞLU}

\section{Gelişmekte Olan Ülkelerde Sermaye İthali ille Sanayileşme}

"Şeytanca" bir düşünce olarak nitelenen borçlanarak sanayileşme ana fikri bugün itibariyle kendisini gelişmekte olan ülkelerde yanlış bir tahmin olarak ortaya koymaktadır (Altvater ve diğerleri, 1987, s.42). Bu ülkelerde yurtdışından alınan kredilerle ilk aşamada bir ticaret bilânçosu açığı göze alınabilecekti, çünkü bu kredilerle ithal edilen sermaye ürünleri sayesinde sanayileşme sürecinin hızlandırılabileceği düşünülmekteydi. Rekabet kabiliyeti olan bir sanayi yapısının başarılı bir şekilde kurulmasından sonra, ikinci aşamada ticaret bilânçosu açığı fazlaya dönüştürülebilecekti. Bu şekilde alınan kredilerin yavaş yavaş geri ödenebileceği düşünülmekteydi (Tetzlaff, 1988, s.28). Fakat bu yalnızca aşağıdaki durumlarda mümkün olabilmektedir: Eğer dış kredilerle finanse edilen projelerin gelirleri uluslararası faiz oranlarının üzerinde ise veya makroekonomik bakışta ekonominin iş verimliliği artışı toplamda faiz oranlarından daha yüksek ise ve aynı zamanda geri akışlardan geri ödemeler kapatılabiliyorsa, dış kredilerin geri ödenmesi mümkün gözükmektedir. Üstelik ilave kapasitelerin inşasına göre fiyat düşüşü olmadan ilave ürünlerin alıma hazır olabilmesi için gerçekten dünya ürün pazarı da genişlemek zorundadır (Altvater ve diğerleri, 1987, s.42).

1960’lı ve 1970'li yıllarda gerek “ithal ikameci strateji” gerekse de "ihracatı çeşitlendirme stratejisi" "borçlanarak sanayileşme" kavramına dönüştürüldü. Gelişmekte olan ülkelerin uzun süre ithal ikamesi ve ihracatın çeşitlendirilmesi stratejileri ile sanayi ürünleri bazında "ikameci işbölümüne" entegre edilmek istenmesi, ekonomi-politik stratejiler olarak tartışıldı. Eğer bunlar, bilinçli olarak iktisat politikalarında alınan önlemler ile takip edilirse, ikisinde de ortak olan şeyin, temelinde "eğitici ve büyütücü korumacılığın" yattığı görülmektedir. Bundan sonra, öncelikle uzun vadedeveya hiçbir zaman- pazar süreçlerinde oluşturulan gelişmeyi iktisat politikaları önlemleriyle yönlendirmek ve hızlandırmak, bir ülke için mümkün ve avantajlı olmamaktadır. Başlangıç noktaları ve ilgili iktisat politikası önlemlerinin somut hedefleri bu iki stratejiyi birbirinden ayırmaktadır (Glismann ve diğerleri, 1987, s.132). Özellikle bugün "eşik ülkeler" diye adlandırılan ülkelerde sanayileşme sürecinin itici gücünü şu unsurların oluşturduğu bilinmektedir: 1)Bir tarafta ekonomik gelişmenin yönlendiricisi ve hammadde sektörünün taşıyıcısı olarak devlet ve onun tasarrufundaki işletmeler. 2) Diğer tarafta ise esas itibariyle tüketim ve yatırım ürünlerini kontrol eden ve aynı şekilde üretken sermayenin artan uluslararasılaşmasının ifadesi de olan ulus ötesi işletmeler. Bu taşıyıc güçler sayesinde oluşan sanayileşme sermaye hareketlerinin artmasına yol açmaktadır: Bu devletin tarafında gelişme yardımı kredileri ve bütçe açıkları şeklinde, ulus ötesi işletmeler tarafında ise sanayi ülkelerinden göç etme veya doğrudan yatırımlar şeklinde ortaya çıkmaktadır. Buna rağmen bu yolla dış borçların hafiflemesi beklentisinin gerçekleşmediği görülmektedir. Çünkü bir taraftan bu şekilde ithalatın zorunlu patlaması, kar transferleri ve buna ilaveten ulus ötesi işletmeler aracılığı ile ithalatın yapay pahalıı̆̆ tam tersine borçlanmanın ağırlaşmasına yol açmaktadır. Diğer taraftan bu durumla paralel giden bölgesel ve bölgeler üstü geçimin sağlanması açısından tarımın ihmali ve ihracat sektörüne yani dünya pazarına yönlendirilmesi ve bununla bağlantılı olarak gıda maddesi ithalatı yeniden ek döviz ihtiyacı doğurmaktadır. Bir taraftan yatırım faaliyetleri borç servisini (faiz ve anapara taksitleri) karşılayacak kadar karlı olmalıdır, yani üretimde elde edilen artı değerin bir parçası olmalıdır, diğer taraftan da üretimde elde edilen ürünlerin dünya pazarında 
satılabilmesi gerekmektedir - yani çoğunlukla Amerikan Doları olarak ödenen dövizi kazanabilmeli$\operatorname{dir}$ (Wendt, 1988, s.67).

Prensipte gelişmekte olan ülkelerde sanayi üretimine başlanması, gerek iç pazarlara gerekse de dış pazarlara hizmet edebilir. Karşılaştırmalı üstünlükler veya dezavantajlar iç pazarda ithal ürünlerini, dünya pazarında da yabancı üreticileri kovmak yönünde ne kadar etkili olabilmektedir? İthal ikamesi ve ihracatı çeşitlendirme stratejileri gelişmiş sanayi ülkelerinde gerçekleşmelerinden ve devlet önlemlerinden bağımsız olarak gelişme sürecinin doğal bir ön sürecidir. Yerli işletmeler mal ithalatlarında pazar şanslarını görebilirler. Eğer bunlar bizatihi ithal edilen ürünleri rekabet gücü olacak şekilde içeride üretebilirlerse, önce ithalatı yerli üretimle ikame edebilirler. Eğer yerli işletmeler ithal ikameyi gerçekleştirebilirlerse, yalnız o zaman bundan sonraki adımda yabancı pazarlara da açılımları tutarlı olur. İade edilen doğal ithal ikame ve ihracat çeşitlendirme stratejisini hızlandırmayı hedefleyen "gelişme korumacılı̆ı" konusunda, aşırı uygulanmadığı sürece, tamamen önemli nedenlere dikkat çekilmektedir. Bu konuyla ilgili olarak özellikle işverenlerde ve çalışanlarda, piyasa üzerinden yeterli olarak ödenemeyen yani uygun ölçüde yalnızca ekonomi politik teşviklerle oluşan, hizmet içi eğitim süreci gösterilmektedir (Glismann ve diğerleri, 1987, s.133). Eğer az gelişmiş ülkelerin dünya pazarına yönelik sanayileşme süreci azgelişmişliği yenmek değilse, şu soru cevap beklemektedir. Neden bu süreç bu ülkelerin birçoğunun yönetimleri tarafından özel bir biçimde desteklenmektedir? Bu sorunun cevabı şöyle verilmektedir. Eğer komisyon ve rüşvet kavramları ile ifade edilen sorunlar bir tarafa bırakılacak olursa, cevap şöyledir: Bu süreç işgücünün doğrudan sömürülmesine izin verse de birçok insan bu sürece çalışanların çıkarına gelişme potansiyeli içeren bir sanayi yapısı ortaya çıkaracak diye umut bağlamaktadır. Bu umut, bahsedilen sanayi gelişmesinin bağımlı tarım ve hammadde üretiminden başka olacağı, kendiliğinden devam eden bağımsız bir gelişme ve kabiliyeti olan bir sanayi yapısı oluşacağı kabulüne dayanmaktadır (Fröbel ve diğerleri; 1977, s.596). Fakat burada umuttan ziyade zorlamalar rol oynamaktadır. Uluslararası klasik işbölümü eşitsiz mübadeleye yol açmakta ve gelişmekte olan ülkelerin perspektifinden bakıldığında genellikle bu bilinmektedir. Birçok yönetimler ülkelerinde ister ithal ikame ile ister ihracatın çeşitlendirilmesi ile olsun sanayileşmeyi gerçekleştirmeye çabalamaktadırlar. Çünkü gelişmekte olan ülkeler sanayi ülkelerinin ürünlerine muhtaç bulunmaktadırlar veya muhtaç olduklarına inanmaktadırlar.

Gelişmekte olan bir ülkeye yabancı yatırımları çekmek için çoğu zaman yalnızca ekonomik faktörler sorumlu tutulmamalı aynı zamanda bu ülkelerde yaygınlaştırılan demokratik temel koşulların da çoğunlukla sorgulanması gerekmektedir. Örneğin Filipinler (Business International, 27 November 1974) ve Güney Kore'de (Deutsche Gesellschaft für Wirthschaftliche Zusamenarbeit, 23 März, 1976) bu sorgulamanın yapılması gerektiği gibi.

Sermaye için düşünülen uygun politik koşullara grev yasağı ve sendikal örgütlenmelerin baskı altına alınması da dâhil edilmektedir. Bunlarla ücret artışlarından ve iyileştirilmiş çalışma koşullarının yüksek maliyetinden korunmayı göreceli olarak garanti etmeye niyetlenilmektedir. Yabancı sermayeyi ülkelerine çekmek isteyen birçok gelişmekte olan ülkede sendikalar ve sendikal faaliyetler ya Bahreyn, İran ve Tayland'da olduğu gibi yasaklanmış, ya da Hong Kong, Hindistan, Malezya, 


\section{Zeki KARTAL | Hakan ACAROĞLU}

Filipin ve Güney Kore'de olduğu gibi politik olarak parçalanmış ve engellenmiş veya Endonezya, Singapur ve Mısır'da olduğu gibi politik olarak satın alınmış ve uyumlulaştırıımıştır. Serbest üretim bölgelerinin ve dünya pazarı için üretim yapan fabrikaların faaliyette olduğu birçok ülkede grev hakları ya yasaklanmış veya baskı altında tutulmaktadır (Fröbel ve diğerleri, 1977, s.546).

\section{Gelişmekte Olan Ülkelerde Sermaye İthalinin Ekonomik Büyümeye ve Tasarrufa Etkisi}

Sermaye ithali, borçlanmayla büyüme (Growt cum Debt) yaklaşımı içerisinde ekonomik büyümeyi gerçekleştirecek yatırımı yapmak için gerekli olan tasarruf açığını doldurma fonksiyonuna sahiptir. Burada ekonomik büyüme ile bağlantılı olan gelir artışı aşırı bir tasarrufa yol açacak. Bu önce yatırım için ve sonraki büyüme dönemlerinde ise borç servisi için kullanılabilecektir (Bigler, 1987, s.51).

Dış sermaye yardımının ekonomik büyüme ve tasarruf etkisi tartışmalı bulunmaktadır. Bazı yazarlar alıcı ülkelerde sermaye ithali ile net dışsal büyüme ve yerli sermaye stoku elde edilebilineceğini kabul ederken (Rosenstein-Rodan, 1961, s.679-733; Chenery ve Strout, 1966, s.679-733), bir dizi yazar da regresyon analizlerinin ampirik sonuçlarına dayanarak (Bigler, 1987, s.20; Agarwal ve diğerleri, 1984, s.69) sermaye ithalinin ekonomik gelişmeyi hızlandırmadığını ortaya çıkarmıştır (Timmermann, 1982, s.69).

Bunlar ithal edilen sermayenin devam eden yatırımlardan çok tüketime gittiği düşüncesini temsil etmektedirler. Bu yapılırken birçok açıklama imkânı göz önünde bulundurulmaktadır: Sermaye malların finanse etmek için ihraç edilen tüketim malları, şimdi sermaye ithalinden dolayı bizzat içeride tüketilebilmektedir (Dürr, 1977, s.314). Bu yerli tasarrufun negatif gelişimine yol açmaktadır. Bu şekilde yetersiz sermaye birikiminin neden olduğu yatırım daralması sebebiyle ithal edilen sermayenin ekonomik büyümeye etkisi az olmaktadır (Eaton ve Gersovitz, 1981, s.289). Ayrıca, sermaye ithali bazı malların dışarıdan ithali için sürekli savurganca harcanmaktadır ki bu mallar uygun bir tasarrufla içeride bizzat üretilebilirdi (Konrad, 1967, s.43; Agarwal ve diğerleri, 1984, s.87). Ayrıca kamusal tasarruf da düşerdi, çünkü devlet kamusal sermaye yatırımın finanse etmek için vergi artırımına gitmezdi (Fischer, 1982, s.75). Eğer sermaye ithali, örneğin istihdam programlarında olduğu gibi altyapı hizmetlerine akarsa, özellikle bu durum bir tüketim artışına yol açmaktadır. Çünkü mevcut ortam bir talep artışına neden olmakta ve böylece ithalat isteği uyandırmaktadır (Gerster, 1982, s.22). Eğer sermaye ithali yatırımda kullanılır ve üretim artışı tamamen iç pazara yönelik olursa yine benzer bir davranış ortaya çıkmaktadır. Birinci olarak ithalat için ihracat gelirleri yani döviz oluşturulamazken, ikinci olarak da bu malların üretimi için gerekli olan ara malların sevkiyatından dolayı ithalat talebi artardı. Keza bu ürün, üretim artışının yarattığı gelir etkisiyle satın alınır, bu da tüketim artışına ve tasarruf miktarının azalmasına yol açar.

Diğer kabul edilen bir görüş ise şudur: İthal sermayenin neden tasarruftan, dolayısı ile de yatırımdan çok tüketime gittiğinin temelinde "absorbsiyon yaklaşımının" yattığıdır. Buna göre bir ülke sermayesinin absorbsiyon yeteneği, karşııklı etkileşim içerisinde olan diğer faktörlerin eksikliği ile sınırlıdır. Eğer, örneğin belirli bir yatırım malının üretimine, ithalatın sınırlanmasıyla, rekabet avantajı sağlanırsa, bu durumda diğer yatırımlar zayıflarken bu dalda yatıımlar yoğunlaşır. Bundan 
dolayı yatırım miktarları yerli sermayeye ilave olarak gelen ithal sermaye ile önemli ölçüde bir artış göstermemektedir. Bu şekilde iç tüketim artmakta (Jungfer, 1991, s.231) ve arzu edilen iç tasarruf oluşamamaktadır.

Büyüme teorisi artan gelirlerle normalin üstünde tasarruf yapılacağını temsil ederken (Leibenstein, 1957) ve böylece brüt toplumsal üretim sermaye sahipleri ile işgücü arasında sermayedarların lehine yoğunlaşırken (Schönherr, 1983, s.69), ampirik araştırmalar bu gelir avantajının genellikle çok az tasarruf eğilimi gösterdiğini ortaya koymaktadırlar (Griffin, 1974 ve Tadora, 1977, s.156; Baran, 1969, s.110). Bu gelirler bir taraftan gayrimenkule, altına, seyahatlere ve ithal edilen lüks mallara harcanmakta (Gerster, 1982, s.23 ve Elsenhans, 1981) ve diğer taraftan sanayi ülkelerinin çekici görünen sermaye piyasalarına ve kısmen de sermaye kaçış yollarına yatırımaktadır. Yüksek enflasyon oranı; negatif reel faiz politikası; yanlış para politikasının işaretleri olarak kredi piyasası-sisteminin gelişme durumu ve düşük reel faiz gelirinden dolayı bu ülkelerde tasarruf cazip olmamaktadır (Fischer, 1982, s.16 ve Mc Kinnon, 1981, s.365-381). Her şeye rağmen açılan düşük tasarruf mevduatları, yüksek faizler için zorunlu ihtiyat oranı düşüldükten sonra kredi olarak verilmektedirler (Bender, 1992, s.515). Fakat gelişmekte olan ülkelerde düşük gelirlilerin tasarrufları da piyasa üzerinden etkin bir şekilde dağıtılamıyor, çünkü bu ülkelerde insanların büyük bir bölümünün yaşadığı geleneksel kırsal bölgelerde para ve sermaye piyasaları gelişme ve parasallaşma derecesi olarak zayıf karakterdedir. Böylece tasarruflar ya yastık altına gitmekte veya kendi küçük işletmelerine yeniden yatırılmaktadırlar (Nödinger,1987, s.18).

Yukarıda teorik çerçeveyi bu şekilde koyduktan sonra makalenin amacına uygun bir şekilde Türkiye'de 1920'li yıllardan başlayarak çalışmanın zaman sınırlamasının başlangıcı olan 1964'e kadar ekonomik gelişmenin belirgin evrelerine genel olarak değinmek açıklayıcı olacaktır.

\section{Türkiye'de Toplumsal ve Ekonomik Gelişme Hedefi Olarak Sanayileşme}

Türkiye'de iktisadi ve toplumsal gelişmenin ana hedefinin, 1920'li yıllarda modernizm teorileri çerçevesinde ve devlet öncülüğünde "kapitalist gelişme stratejisiyle" sanayileşme olarak aynı zamanda sermaye ithalinin de Türkiye'nin ekonomik gelişmesine katkı yapmasını dışlamayacak şekilde konulduğu görülmektedir. Örneğin 1920'li yılların başında dönemin hükümeti tarafından Fransa ve ABD’nin para-kredi piyasalarında sermaye ithalinin imkânları araştırımaktadır, fakat o günün koşullarında bu girişimin başarıı olamadığı görülmektedir ${ }^{1}$. 1920'lerde sanayileşmeyi teşvik amacıyla devletin önemli kararlar almış olduğu bilinmektedir. Bu kanun ve kararların tanınmışları 1927 'de çıkartılan “Teşvik-i Sanayi” kanunu, yine 1927'de kurulan "Ali İktisat Meclisi” ve 1929'da oluşturulan "Milli iktisat ve Tasarruf Cemiyeti'dir." Diğer taraftan 1925'te çıkarılan "Takrir-i Sükûn Kanunu" ile de ekonomiye yapılan ve yapılacak olan eleştirilerin önünün kesilmek istendiği görülmektedir. Bu yıllarda yukarıdaki yasa ve kararlarla liberal ekonomi politikalarının desteklendiği söylenmektedir (Çavdar, 1995, s.1077).

\footnotetext{
${ }^{1}$ Bu bilgiler Tezel'in (1986) kitabında daha geniş bir şekilde yer almaktadır.
} 


\section{Zeki KARTAL | Hakan ACAROĞLU}

Cumhuriyet hükümeti 1923-1929 arası ekonomik dönemde eskiden Rum ve Ermeni sermayesinin yerine getirdiği fonksiyonların tümünü yeni oluşan Müslüman-Türk girişimcilere transfer etmektedir. Hükümet bir taraftan iş bankası aracılığı ile yerli sermayenin örgütlenmesini teşvik ederken, diğer taraftan da sermaye ithaline izin vermektedir (Keyder, 1995, s.1067).

1920'lerden beri devam eden, 1929'da had safhaya ulaşan dış ticaret açığı ve 1930 dünya ekonomik krizinin etkisiyle sanayileşmenin hızını arttırmak için yeni bir iktisat politikası arayışı içerisine girilmektedir. Arayış sürecinde ise hemen hemen herkesin devletçiliği savunmakta olduğu görülmektedir ve 1937 yılında da devletçilik ilkesi anayasa maddesi haline getirilmiş bulunmaktadır (Çavdar, 1995, s.1078).

Bu iktisat politikalarının uygulanabilmesinin bir yolu olarak yine sermaye ithali düşünülmektedir. Fakat kriz dolayısıyla yabancı sermayenin özellikle de ABD sermayesinin buna ilgi göstermemesi nedeniyle sanayileşme programlarının uygulanmasının bir başka yolu olarak "devlet kapitalizmi" ne başvurulmaktadır (Tezel, 1986).

İkinci Dünya Savaşı'nın hemen akabinde "bürokrat-devletçi” ekonomik gelişme politikalarının gerçekleşebilmesi için yine büyük miktarda bir sermaye ithali öngörülmektedir. Bu nedenle Cumhurbaşkanı İsmet İnönü'nün ABD’den 500 milyon Dolar tutarında kredi istediği kayıtlarda bulunmaktadır (Tezel, 1986, s.192).

İkinci Dünya savaşı sonrası oluşan yeni koşullar altında bu "bürokrat-devletçi” programın 1947 yılında rafa kaldııldığına tanık olunmakta ve sanayileşme politikalarında ağırlığın tekrar özel sermayeye verildiği görülmektedir. Ancak Türkiye'de devletçiliğin "ekonomi toplumu" tasarımında o kadar büyük bir etkisi bulunmaktadır ki; haklı olarak DP (Demokrat Parti) döneminde uygulanan liberal iktisat politikalarına "liberal devletçilik" denmektedir². DP döneminde uygulanan ekonomik gelişme modelinin finansmanı da yine sermaye ithaline dayanmaktadır. Bunu da ağırlıkla ABD'nin Türkiye’ye ilişkin “Marschal Planı'nın” oluşturduğu ve Türkiye'nin ABD'den 1946-1950 döneminde 177 milyon dolar tutarında bağış ve 117 milyon dolar tutarında kredi aldığı kayıtlardadır (Tezel, 1986, s.195).

Özetle Türkiye'de daha Cumhuriyetin ilk yıllarından itibaren toplumsal ve iktisadi gelişmenin genel hedefi olarak sanayileşmeyi gerçekleştirebilmek için sermaye ithaline başvurulduğu görülmektedir. Burada genel gelişme hedefine uygun olarak sanayileşmenin siyasal bir süreç olduğu olgusunun da altının çizilmesi gerekir ${ }^{3}$ Türkiye'de sanayileşme "doğal ve teknik bir seçim (özelliği) değil (bilakis) siyasal sonuçları için arzulanan bir süreç” (İnsel, 2003, s.179) karakterine sahip bulunmaktadır.

Aşağıda uygulanabilmesi için sermaye ithaline en çok ihtiyaç duyulduğu görülen ithal ikameci gelişme stratejisinin özelliklerine genel hatlarıyla değinilmektedir.

\footnotetext{
2 Bu konu İnsel'in (1996) kitabında daha geniş bir şekilde yer almaktadır.

${ }^{3}$ Bu konu insel'in (2003) kitabında kapsamlı olarak ele alınmaktadır.
} 


\subsection{0 - 1979 Dönemi İthal İkameci Sanayileşme Stratejisi}

İthal ikameci kalkınma stratejisi geniş anlamıyla iç pazara yönelik bir stratejiyi tanımlamaktadır. Bununla yerli üretim yapısının genişlemesi ve yaygınlaşmasının başarıması gerekmektedir. Bu gerçekleştirilirken şimdiye kadar ithal edilen ürünler (hammadde, gıda maddeleri, sanayi ürünleri vs.) ülke içinde üretilen ürünlerle ikame edilmektedir. İktisadi sektörlerin tüm ürünleri, ithal ikamesinin konusu olabilmesine rağmen, gelişmekte olan ülkeler geçmişte bu stratejiyi hemen hemen sırf sanayileşme stratejisi olarak algıladılar. Bunun bir yönüyle sanayileşmenin gelişme ile bir tutulmasında, diğer yönüyle de gelişmekte olan ülkelerin ithalatlarının ağırlıkta sanayi ülkelerinden yapılmış olmasıyla ilintili bulunmaktadır. Bu ülkelerin gıda maddeleri ithalatı bir olanağa işaret etmektedir ki o da bu ülkeler tarım ürünleri ithalatını da yerli üretimle ikame edebilmektedirler (Knal ve Wagner, 1986, s.48).

Bir sanayileşme politikası olarak ithal ikame politikasının manası, iç pazara yönelik üretimi gerçekleştirmek ve ithalat için harcanmak zorunda kalınan dövizi tasarruf etmek amacıyla yerli bir sanayinin kurulmasıdır. Burada sanayinin teşviki için gerekli olan altyapının devlet tarafından yapılması gerekmektedir. Bu tür sanayileşmenin sonucunda genellikle ikili bir ekonomi oluşmaktadır: Düzenli çalışma koşulları altında çalışılan sektörler ve bunun karşısında yasaların geçerli olmadığı sektörler (enformel sektörler). Sanayinin teşviki genellikle sanayinin kurulduğu yerler olan şehirlerin teşvikiyle paralel gitmekte ve kırsal alanlar inmal edilmektedirler. Bununla paralel olarak giden kırsal kesimdeki yaşam koşullarının kötüleşmesi, gelişmekte olan ülkelerdeki iç göçün büyük bir bölümünün en önemli sebebi sayılmaktadır.

Toplumsal temel koşullar dikkate alındığında ithal ikameci sanayileşmede herhangi bir ülkede ihtiyaç olan şeyin üretilme şansı oluşmaktadır. İthal-ikame ile bağımsız bir politika izleme çabası, geçmişte birçok Latin Amerika ülkelerinde önemli bir rol oynamıştır. Birinci Dünya Savaşı ve aynı şekilde özellikle 1930'lu yıllarda dünya ekonomik krizi esnasında ve íkici Dünya Savaşı esnasında, bir dizi gelişmekte olan ülke dış ticaretleri büyük ölçüde durduğundan dolayı bu politikayı uyguladılar.

Bazı gelişmekte olan ülkelerde çok özel koşullar altında zayıf bir ithal ikameci sanayileşme mümkün oldu. Örneğin Latin Amerika'nın bir parçasında 1930-1945 yıllarında dünya ekonomisine entegrasyondan kısmi kopuş esnasında mümkün olabilmiştir. Bu zaman diliminde ithalat yasağı koruması altında (çünkü güçlü sanayi ülkeleri bu dönemde kendi problemleriyle meşguldürler ve bu yüzen müdahalede bulunmadılar) bazı gelişmekte olan ülkelerin sınırlı iç pazar ihtiyaçlarının temini bu ülkelerde mütevazı ve katlı bir sanayi oluşumuna yol açtı. Fakat bu çok hızlı bir şekilde

yerli alım gücünün sınırına dayandı ve sanayi savaş sonrası dönemde düzenli bir şekilde durgunluk yaşayarak çöktü (Fröbel ve diğerleri, 1977, s.29).

İthal ikameci politikanın gerçekleşmesi bazı problemlerin çözümüne bağı bulunmaktadır: Bunların başında yetersiz sermaye ve adaletsiz gelir dağılımı veya iç pazardaki yetersiz talep gelmektedir. Doğrusu gelişmekte olan ülkelerin iç pazarlarında genellikle yeterli talep yok, fakat diğer taraftan lüks mallara talep bulunmaktadır. 


\section{Zeki KARTAL | Hakan ACAROĞLU}

Aslında mantıklı gözüken durum, ithal ikameci stratejinin yapısal problemler nedeniyle gelişmekte olan ülkelerin aleyhinde etki göstermesidir. İthal ikamede sıkça şu merkezi problemler ortaya çıkmaktadır: Yüksek değerli tüketim maddeleri (otomobil, çamaşır makinesi vb.) ithalatının yerli üretimle ikame edilmesi yaşam standardının genel olarak yükselmesine neden olamamaktadır, çünkü bu ürünlere olan talep varlıkıı bir azınlıkla sınırlı kalmaktadır.

Ithal ikameci strateji özellikle başlangıç aşamasında otomatik olarak döviz tasarrufuna yol açmaktadır. Şimdi tüketim malları yerine ithalatı ikame edecek ürünler için sermaye malları, hammaddeler ve aramaların ithal edilmesi gerekmektedir. Bunların ithalatı için ihtiyaç olan döviz ya ihracat gelirlerinden veya yabancı krediler biçiminde sermaye ithalinden elde edilmektedir. Eğer ithal ikamesi sermaye ve ara mallar üretebilirse, bu şartlar altında döviz tasarrufu yapılabilir. Fakat burada özellikle yukarıda bahsedilen yetersiz sermaye problemi ve sınılı iç talep etkisini göstermektedir. Bir taraftan sermaye ve ara malları sanayisi kurmak, özellikle sermaye yoğun olmakta (sanayi ülkelerinden ithal edilen teknoloji) ve bununla birlikte gelişmekte olan ülkelerin koşullarına çok az uymaktadır. Diğer taraftan sınırlı olan iç talep bu işletmelerin kapasite kullanabilmelerini ve büyük yararlar sağlayabilmelerini ortadan kaldırmaktadır.

Ithal ikameci kalkınma stratejisi modelinin ekonominin kendisini yeniden üretecek gerekli döviz gelirlerini ortaya koyamaması bunun sonucu olarak her yıl ortaya çıkan ticaret açıkları, işçi dövizleri ve dışarıdan alınan borçlarla kapanmaktaydı. 1970'li yılların başlarında başlayan dünya ekonomik krizi bu iki kalemin yetersiz kalmasına sebep oldu (Keyder, 1995, s.1071) ve ithal ikamesine dayanan sanayileşme stratejisi 1979 'da krize girmiş oldu. Bilinen 24 Ocak kararları ile ekonominin yeniden yapılanması hedeflenmiş ve ihracata dayalı sanayileşme stratejisine geçilmiştir.

Ithal İkameci Gelişme stratejisinin uygulandığı 1960-1979 döneminde Türkiye’nin sanayileşmesini sermaye ithali yoluyla sürdürmek zorunda kaldığı görülmektedir. İlgili dönemde program kredileri azalırken yatıım, proje ve ticari kredilerin artışına tanık olunmaktadır. Bu durum devletin tercih ettiği ekonomik kalkınma tasavvurunun doğal bir sonucu olarak yorumlanmaktadır (Gürsel, 1995, s.477).

Benzer ülkelerde olduğu gibi Türkiye'de de sermaye ithalinin nedeni yüksek yatırım talebine karşın düşük tasarruf oranına sahip olmasıdır. 1960'ı ve 1970'li yıllarda Türkiye \%15'in altında tasarruf oranına ve \%20'ye yaklaşan yatıım oranına sahip ülkeler arasında gösterilmektedir (Tuncer, 1995, s.1127). Düşük tasarrufun nedeni ise cumhuriyet döneminde sermaye birikimini gerçekleştirecek ve uygun bir sanayileşme modeli oluşturacak girişimci bir sınıfın olmamasına bağlanmaktadır. Bu koşullar altında Türkiye hızlı ekonomik büyüme talebini gerçekleştirebilmek için ihtiyacı olan sermayeyi ithal etmek zorunda kalmaktadır. 


\subsection{Sonrası İhracata Yönelik Sanayileşme Stratejisi}

Yabancı pazarlara yönelik sanayileşme stratejisi bir taraftan geleneksel ürünlere bağlı ihracatın arttııımasını amaçlarken, aynı zamanda diğer taraftan bugüne kadar daha üretilmeyen ürünlerin (Örn. yeni tarım ürünleri, mamul ve yarı mamul sanayi ürünleri gibi) ihracatını genişletmeyi hedeflemektedir. Son adlandırılan ürünlerde genellikle yerli ara malları ve hammaddeleri veya hemen hemen yalnızca ithal edilen girdiler kullanılmaktadır. Burada değişik nedenlerden dolayı yerli girdilerin tercih edilmesi gerekli bulunmaktadır. İhracat çeşitlendirmesinin yardımıyla gelişmekte olan ülkenin dünya ekonomisindeki işbölümüne eklemlenmesi aracılığı ile ekonomik gelişmesinin hızlandıııması amaçlanmaktadır. Buna göre bir veya birkaç ihraç ürüne tamamen tek taraflı bağımlılıktan kaçınmak gerekmektedir (Knall ve Wagner, 1986, s.49). İktisat politikası stratejisi olarak ihracatın çeşitlendirilmesi, devletin ihracatı ve ihraç ürünlerini genişletmesinin teşvikini içermektedir (Glismann ve diğerleri, 1987, s.132).

Eğer yerli üretim koruma duvarlarının arkasında genişleyip yayıımışsa, gelişmekte olan ülkeler bunun ihracatın çeşitlendirilmesi için ne kadar dezavantajlı olduğunu gösteren birçok örnek sunmaktadırlar. Böylesi bir yaklaşım genel olarak yüksek üretim masrafları ve kapasitelerinin tam kullanılamaması gibi etkin olmayan üretim metotlarına yol açmaktadır. Bundan dolayı gelişen veya sanayileşen bir ekonomide büyüme süreci ve etkinliğin artması sırasıyla değil mümkün olduğu kadar aynı zamanda gerçekleşmesi gerekmektedir. Çünkü yerli üretim süreci üzerine etkinliği teşvik edici olarak rasyonel hareket edilmektedir, bundan dolayı yabancı rekabetle erken karşılaşma aranmaktadır. Dışa dönük sanayileşme stratejisinde gelişmekte olan ülkeler bazı önlemler alabilmektedirler. Aşağıda bunlar arasından bazıları gösterilmektedir: kalite kontrolleri, ihracat primleri, sübvansiyonlar, vergi indirimleri, ihraç ürünlerinde kullanılmak için ithal edilen materyallerde gümrük geri ödemeleri; ucuz ihracat kredileri ve ihracat risk garantileri, düşük nakliye hizmetleri ve kur politikası önlemleri (yerli paranın değerinin düşürülmesi). İhracatın arttııılması için önemli bir kurumsal koşulda fonksiyon yeteneği olan ihracat altyapısının elde olmasıdır. Bundan anlaşılan yatırımlar ve firmaların tek başına yapamayacağı örneğin ulaşım yolları, limanlar, serbest ticaret bölgeleri, dış ticaret odaları, dış pazar araştırmaları, numune fuarları ve ihracat özendirme konsülleri gibi. Kurumsallaştırılmış ihracat teşvikinin nasıl etkin olabileceğini Singapur ekonomik gelişme idare heyeti göstermiş bulunmaktadır (Knall ve Wagner, 1986, s.51).

İhracata yönelik strateji için çıkış noktasını dünya pazarındaki talep oluşturmaktadır. Bu sanayileşme stratejisi ister hammaddeleri işleyerek olsun, isterse emek yoğun sanayi dallarının kurulmasıyla olsun dünya pazarı için ihracat yapmaya yönelmiştir. ihracata yönelik strateji gelişmekte olan ülkelerin gerek hammaddelerin işlenmesinde (ulaştırma maliyetleri) gerekse de emek yoğun üretimde (ücret maliyetleri) sanayi ülkeleri karşısında önemli bir karşılaştırmalı üstünlüklere sahip olmasını gerektirmektedir. Buradan hareketle bu strateji ağırıklı olarak dünya pazarındaki sinyallere göre tasarlanmakta ve politik destek bu güçleri kuvvetlendirmek için iktisat politikası teşvikleri olarak gerçekleşmektedir (Pollak, 1991, s.141). 


\section{Zeki KARTAL | Hakan ACAROĞLU}

Dünya pazarına kuvvetli bir yönelmeyle, gelişmenin milli bakış açısından anlamı: Kapitalist sistemin kurallarının bağlayıcı olmasıdır. Buna ek olarak batılı gelişme modeli ve buna ait olan düşünme ve davranış rasyonalizmleri alınmaktadır. Bu da alternatif gelişme imkânları ve kültürün korunmasını neredeyse tamamen dışarıda bırakmaktadır (Altvater ve diğerleri, 1987, s.73).

Tüm bunlardan bağımsız olarak aşağıda sermaye ithalinin Türkiye'de ekonomik büyüme ve iç tasarrufu ne ölçüde etkilediği ampirik bir uygulama ile test edilmektedir.

\section{Türkiye'de Sermaye İthalinin Ekonomik Büyüme ve Yurtiçi Tasarrufa Etkisi}

\subsection{Yöntem}

Nedenselliğin varlığını ve yönünü sınamak için ilk girişim Granger (1969) tarafından önerilmiştir. Literatürde bu testlerin ismi Granger-nedensellik sınamaları olarak geçmektedir. Granger sınaması, iki değişken arasındaki nedensellik ilişkisinin varlığını belirlemede uygun bir yaklaşım olarak bilinmektedir ve bu çalışmada da kullanılmaktadır. Bir zaman serisi (X) başka bir zaman serisi (Y)'nin Granger-nedeni ise; X'in geçmişteki değerleri Y'nin şimdiki değerleriyle regresyona tabii tutulduğunda, bu regresyon sonucunda Y'ye ait hata teriminin azalıyor olması demektir. Standart bir Granger-nedensellik sınaması uygulayabilmek, serinin değişkenlerinin durağan olmasıyla mümkün olabilmektedir. Dolayısıyla, iki değişken öncelikle durağanlık sınamasına tabii tutulmalıdır. İki değişkenin birim kökleri ve durağan olup olmamasının incelenmesi için Phillips-Perron testi (Phillips ve Perron, 1988) çeşitli sınamalardan bir tanesidir ve bu çalışmada da kullanılmaktadır.

Bu çalışmanın yönteminde sermaye ithali temsilen Türkiye'nin vadelerine göre toplam dış borç stokundan elde edilmiş borç verileri kullanılmaktadır. GSYiH ve Dış borçlar arasındaki Grangernedenselliği sınamak için, iki çift yönlü model belirlenmektedir. Bu modellerden bir tanesi GSYiH için ve diğeri ise Dış borçlar içindir. Eğer iki değişken durağan ise, Granger-nedensellik testinin standart formu, takip eden şekliyle belirlenebilir":

$$
\begin{aligned}
& \Delta Y_{t}=\alpha_{11}+\sum_{i=1}^{L_{11}} \beta_{11 i} \Delta Y_{t-i}+\varepsilon_{11 \mathrm{t}} \\
& \Delta Y_{t}=\alpha_{12}+\sum_{i=1}^{L_{11}} \beta_{11 i} \Delta Y_{t-i}+\sum_{j=1}^{L_{12}} \beta_{12 j} \Delta X_{t-j}+\varepsilon_{12 \mathrm{t}}
\end{aligned}
$$

\footnotetext{
4 Bu çalışmadaki iki değişken arasındaki Granger-nedenselliği sınamak için ele alınan model için Granger (1969, s.431)'de ele alınan sıfır ortalamalı iki durağan zaman serisiyle meydana gelen basit nedensel modelden yararlanılmıştır. Ancak Granger'in modelinde ele alınan değişkenler fark modelleri olarak değil, sadece şimdiki zaman ve gecikmeli zaman değerleri olarak ifade edilmektedir. Bu modelleri fark değişkenleri cinsinden ifade etmek de mümkündür. Eşitliğin her iki tarafının farklarının alınması suretiyle elde edilen bu yaklaşımı Yang (2000)'de de görmek mümkündür. Yang'ın Tayvan için enerji ve GSYiH arasında ele aldığı nedensellik ilişkisi metodolojik açıdan bu çalışma için de yol gösterici bir özelliğe sahiptir.
} 


$$
\begin{aligned}
& \Delta X_{t}=\alpha_{21}+\sum_{i=1}^{L_{21}} \beta_{21 i} \Delta X_{t-i}+\varepsilon_{21 \mathrm{t}} \\
& \Delta X_{t}=\alpha_{22}+\sum_{i=1}^{L_{21}} \beta_{21 i} \Delta X_{t-i}+\sum_{j=1}^{L_{22}} \beta_{22 j} \Delta Y_{t-j}+\varepsilon_{22 \mathrm{t}}
\end{aligned}
$$

Burada $\Delta$; fark operatörüdür, Yt ve Xt sırasıyla GSYiH ve dış borçlardır. L gecikme sayısıdır. $\alpha$ ve $\beta$ tahmin edilecek parametrelerdir ve $\varepsilon$ t hata terimidir. Denklem (2) ve (4) kısıtlanmamış formlardır. Denklem (1) ve (3) kısıtlanmış formlardır. Fakat denklem (1) ve (2) dış borçlarının geçmişteki gecikmelerinin katsayılarının tümüyle sıfır olabileceğini belirlemek için bir ikili meydana getirmektedir. Gecikmeli değerlerin katsayıları sıfır olabilir mi sorusu $\mathrm{F}$ istatistikleri hesaplanarak sınanır. Eğer denklem (2)'deki X'in gecikmeli değerlerindeki tahmin edilen katsayı anlamlı ise, bu durumda, bu denklem Y'nin bizzat kendi gecikmeli değerleri tarafından açıklanamayan bir kısmının açıklanabileceği anlamına gelmektedir. Bu durum ise, $X$ Y'ye nedensel olarak bağlı ve $X$ Y'nin Grangernedeni olarak ifade edilmektedir. Benzer olarak, denklem (4)'te de gerçekleştiğinde $Y$ X'in Grangernedenidir denilir.

Engle ve Granger'e (1987) göre, eğer iki değişken eşbütünleşik iseler, sonrasında daha kapsamlı bir nedensellik sınaması olan, hata düzeltme modeli uygulanmalıdır (prosedürün detayları için bknz.. (Yang, 2000: 311)). Hata düzeltme modeline eşbütünleşme regresyonundan elde edilen hata teriminin gecikmeli değerlerinin dâhil edilmesi, nedenselliğin oluşabilme etkileri için bir ekstra durum sağlamaktadır. Böylece, GSYiH ile dış borçların eşbütünleşme özelliği için sınanması gerekliliği oluşur.

Nedensellik sonuçları bağımsız değişkenlerin gecikmeli yapılarına duyarlıdır. Gecikmeleri isteğe bağlı olarak seçmek tahminleri bozabilir ve eksik nedensellik sonuçlarıyla karşı karşıya kalınabilir. Bu çalışmada uygun gecikmelerin seçimine rehberlik etmesi açısından Hasiao (1981) yöntemi Akaike (1969) en son tahmin hatası (FPE) ile birleşerek, Granger-nedensellik testleriyle birlikte ve aynı zamanda Yang (2000)'de gösterildiği şekliyle uygulanmaktadır. Hasiao yöntemi iki basamak içermektedir. İlk basamak, gecikme sırasını (t11) 1'den L11'e değiştirerek kalıntı kareler toplamını hesaplayarak denklem (1)'i tahmin etmektir. En küçük FPE (t11) en uygun gecikmeyi (t11*) belirleyecektir. İkinci basamak denklem (2)'yi tahmin etmektir. Illave bir $\mathrm{X}$ değişkeni için, gecikme düzeyi (t12) 1'den T12'ye tekrar değişir ve yeni denkleme göre oluşturulmuş FPE hesaplanır. Ayrıca, en küçük FPE (t11*, t12) en uygun gecikme (t12*)'ye karar verir. Uygun gecikmeler bir kez belirlendiğinde, nedenselliğin yönünün bir alternatif sınama yolu, basamak 1 ve basamak 2'den elde edilen en küçük FPE'ler ile karşılaştırılır. Eğer FPE (t11*, t12*), FPE (t11*)'den küçük ise, bu durumda, dış borçlar GSYiH'nın Granger-nedenidir denilir. Buna ilave olarak, GSYiH'dan dış borçlara olan nedensellik aynı işlemleri bu kez denklem (3) ve (4) için tekrar ederek tahmin edilebilir. 


\section{Zeki KARTAL | Hakan ACAROĞLU}

\subsection{Veri Ve Ampirik Sonuçlar}

Dış borçlar ile GSYiH ve tasarruflar arasında nedensel bir ilişkinin varlığını araştırmak üzere, 1964-2012 dönemini kapsayan yıllık veriler kullanılmaktadır. Dış borçlar Tüik (2007, s. 621)'den alınan vadelerine göre toplam dış borç stokundan elde edilmiş Amerikan Doları üzerinden hesaplanan verilerdir. GSYiH ve tasarruf verileri, dünya bankası tarafından hazırlanan Dünya Kalkınma Göstergeleri'nce (WDI) sırasıyla, cari Amerikan Doları üzerinden elde edilmiş fert başına milli gelir ve milli gelirin yüzdesi olarak hesaplanan milli tasarruf miktarıdır. Tüm nedensellik ilişkileri, seriye ait tüm yıllar, 1980 öncesi yıllar ve 1980 sonrası yıllar dikkate alınarak incelenmiştir.

\subsubsection{Değişken Tanımlamaları}

Modelde kullanılan değişkenler: GSYiH; cari Amerikan Doları ile fert başına düşen milli geliri, DIŞBORÇ; vadelerine göre toplam dış borç stokundan elde edilmiş verileri, TASARRUF; brüt iç tasarruf miktarını; cari Amerikan Doları ile ve milli gelirin yüzdelik oranı olarak hesaplanan tasarruf miktarını temsil etmektedir.

\subsubsection{Birim Kök Ve Eş Bütünleşme Sınamalarından Elde Edilen Sonuçlar}

Birim kök ve eşbütünleşme sınamalarından elde edilen sonuçlar, Tablo1-4'de yer almaktadır. Tablo-1; 1964-1980, Tablo-2; 1980-2012, Tablo-3; 1964-2012 serisinin GSYiH, TASARRUF ve DIŞBORÇ'u içeren tüm değişkenleri için birim kök sınamalarını göstermektedir. Bu çalışmada birim kökler ve durağanlık için Phillips-Perron testine başvurulmaktadır. Tablo-1'de de görüldüğü gibi, her değişkenin ikinci fark dışındaki Phillips-Perron değerleri (TASARRUF hariç) \%10'luk istatistiksel anlamlıık düzeyindeki -3,24 olan kritik değerden düşüktür. Bu durum serinin TASARRUF dışındaki değişkenlerinin durağan olmadıklarının göstergesidir. Bununla birlikte, serinin tüm değişkenleri için, \%10'luk anlamlılık düzeyinde ikinci farkı alınmış veriler kullanıldığında durağan olmama durumu reddedilebilir. Böylece, Granger-nedensellik modelleri 1964-1980 yılları için ikinci fark verisiyle tahmin edilebilir. Aynı yaklaşımla, 1980-2012 ve 1964-2012 yıllarına ait seriler ise Tablo-2 ve Tablo3 'ten de anlaşılacağı üzere durağanlık koşulunu sağlayan birinci fark verisiyle tahmin edilebilirler.

Tablo 1. Birim-kök sınamaları, 1964-1980

\begin{tabular}{lccr}
\hline \hline & Düzey & Birinci fark & İkinci fark \\
Değişkenler & Phillips-Perron değeri & Phillips-Perrron değeri & Phillips-Perrron değeri \\
\hline GSYiH & -0.988 & -3.174 & $-4.927^{* * *}$ \\
TASARRUF & $-3.266^{*}$ & $-6.865^{* * *}$ & $-8.943^{* * *}$ \\
DIŞBORÇ & -0.507 & -2.583 & $-3.376^{*}$ \\
\hline \multirow{2}{*}{$\% 10$ anlamllık düzeyindeki kritik değer: $-3.240, * * \% 5$ anlamllık düzeyindeki kritik değer $-3.600, * * * \% 1$ anlamllık } \\
düzeyindeki kritik değer -4.380
\end{tabular}


Tablo 2. Birim-kök sınamaları, 1980-2012

\begin{tabular}{|c|c|c|}
\hline \multirow[b]{2}{*}{ Değişkenler } & Düzey & Birinci fark \\
\hline & Phillips-Perron değeri & Phillips-Perrron değeri \\
\hline GSYIH & 1.163 & $-5.163 * * *$ \\
\hline TASARRUF & -1.730 & $-4.285^{* *}$ \\
\hline DIŞBORÇ & 0.386 & $-5.116 * * *$ \\
\hline \multicolumn{3}{|c|}{$\begin{array}{l}\text { * \%10 anlamllık düzeyindeki kritik değer: }-3.223, * * \% 5 \text { anlamlılık düzeyindeki kritik değer: }-3.572, * * * \% 1 \text { anlaml- } \\
\text { lık düzeyindeki kritik değer: }-4.316\end{array}$} \\
\hline \multicolumn{3}{|c|}{ ablo 3. Birim-kök sınamaları, 1964-2012 } \\
\hline & Düzey & Birinci fark \\
\hline Değişkenler & Phillips-Perron değeri & Phillips-Perrron değeri \\
\hline GSYIH & 2.096 & $-5.971 * * *$ \\
\hline TASARRUF & -2.154 & $-6.068 * * *$ \\
\hline DIŞBORÇ & 2.276 & $-5.818 * * *$ \\
\hline \multicolumn{3}{|c|}{$\begin{array}{l}\text { * \%10 anlamllık düzeyindeki kritik değer: }-3.185, * * \% 5 \text { anlamlılık düzeyindeki kritik değer: } \quad-3.508, * * * \% 1 \text { anlamll- } \\
\text { Ilk düzeyindeki kritik değer: }-4.168\end{array}$} \\
\hline \multicolumn{3}{|c|}{$\begin{array}{l}\text { Daha önce de belirtildiği gibi, eğer DIŞBORÇLAR ile GSYiH ve TASARRUFLAR durağan değilseler } \\
\text { ve iki değişkenin lineer kombinasyonu durağan değilse, bu durumda standart Granger nedensellik } \\
\text { sınaması uygulanmalıdır. Fakat eğer DIŞBORÇLAR ile GSYiH veya TASARRUFLAR durağan değilseler } \\
\text { ve bu iki değişkenin serilerinin lineer kombinasyonu durağan ise, bu durumda hata-düzeltme mo- } \\
\text { deli uygulanmalıdır. Böylece, nedensellik sınamalarını uygulamadan önce DIŞBORÇLAR ile GSYiH ve } \\
\text { DIŞBORÇLAR ile TASARRUFLARA ilişkin seriler için eş bütünleşme sınamaları uygulanmalıdır. Tablo- } \\
\text { 4'de GSYiH-DIŞBORÇ ve TASARRUF-DIŞBORÇ değişkenlerinin belirtilen } 3 \text { farklı zaman serisi için eş } \\
\text { bütünleşme sınamaları yer almaktadır. Tablo-4'de de gösterildiği gibi, eş bütünleşik sınamasının } \\
\text { regresyon değerleri her üç seride de \%10 anlamlılık düzeyinde -3.43 olan kritik değerden büyüktür. } \\
\text { Buna göre, DIŞBORÇLAR ile GSYiH ve DIŞBORÇLAR ile TASARRUFLAR eş bütünleşik değillerdir }{ }^{5} \text {. }\end{array}$} \\
\hline
\end{tabular}

${ }^{5}$ GSYiH-DIŞBORÇ regresyonunda ếnin gecikmeli değerindeki t-kritik değerleri, Seri1, Seri2 ve Seri3 için sırasıyla $-2.92,-193$ ve -2.42 değerlerini almaktadır. Bu t değerleri eşbütünleşme regresyonundaki $\% 5$ anlamllık düzeyinde -3.43 olan değerden büyüktür. Bu durumda eşbütünleşmenin olmadığı $\mathrm{HO}=0$ hipotezi reddedilmemektedir ( $\mathrm{t}>\mathrm{tc}$ ). Her üç seride de $\mathrm{t}>-3.43$ durumu sağlandığı için $\mathrm{HO}$ hipotezi olan en küçük karelerin artıklarının durağan olmadıkları reddedilmemektedir; ya da artıklar durağan değillerdir. Bu durumda GSYiH ve DIŞBORÇ değişkenleri her seri için de eşbütünleşik değillerdir. Aynı durum, TASARRUF VE DIŞBORÇ değişkenleri için de tekrarlanmaktadır. Buna göre; TASARRUF VE DIŞBORÇ değişkenleri her seri için de eşbütünleşik değillerdir, önermesi geçerlidir. 
Zeki KARTAL | Hakan ACAROĞLU

Tablo 4. Eş bütünleşme sınamaları

\begin{tabular}{lrrr}
\hline \hline Değişkenler & Seri1: 1964-1980 & Seri2: 1980-2012 & Seri3: 1964-2012 \\
GSYiH-DIŞBORÇ & -2.92 & -1.93 & -2.42 \\
TASARRUF-DIŞBORÇ & -1.86 & -2.29 & -2.31 \\
\hline$* *$ \%5 anlamllık düzeyindeki kritik değer: -3.43, (50'den küçük gözlem ADF(1) kritik değeri (bkz.. Sjö, 2008, s.23)).
\end{tabular}

Böylece, denklem (1)-(4)'de yer alan eşitlikler kullanılarak standart Granger-nedensellik sınamalarının uygulanmasına geçilebilir.

\subsubsection{Granger-Nedensellik Sınamalarından Elde Edilen Sonuçlar}

Serilerin orjinal formları durağanlık koşulunu sağlamadığından dolayı, Granger sınamaları yürütülürken, değişkenler 1964-1980 dönemi için ikinci ve diğer dönemler (1980-2012 ve 19642012) için birinci fark formlarına dönüştürülmüşlerdir. Birçok gecikme uzunlukları denenmiş ve gecikme yapıları Akaike son hata tahmini kriterince seçilmiştir. Dış borçlar ile hem GSYiH hem de tasarruflar arasındaki Granger-nedensellik sınamalarının sonuçları Tablo-3 ve Tablo-4'de sunulmaktadır. Tablo-3a'da gösterildiği gibi, 1964-1980 döneminde, Gayrisafi yurtiçi hâsıla ile dış borçlar denkleminde, 1.3 e-23 > -1.7 e-31olduğundan, dış borçlar'ın, GSYiH'nın Granger-nedeni olduğu hipotezi kabul edilir. Bu durum, GSYiH'yı, ona dış borçların eklenmesiyle GSYiH'nın geçmiş değerlerinin dâhil edilmesinin, geçmiş değerlerinin dâhil edilmemesinden daha iyi bir şekilde açıllar olarak yorumlanabilir. Tersi olarak, dış borçlar ile gayrisafi yurtiçi hâsıla denkleminde, 3.6 e-19 >-1.7 e-28 olduğundan, GSYiH'nın, dış borçlar'ın Granger-nedenidir olduğu hipotezi kabul edilir. Bu durum, dış borçlara GSYiH'nın eklenmesiyle dış borçların geçmiş değerlerinin dâhil edilmesi dış borçların daha iyi açıklanmasını sağlamaktadır olarak açıklanabilir. Buna ilave olarak, Tablo-3a'da da gösterildiği gibi, GSYiH-Dış borçlar denklemi ve dış borçlar- GSYiH denkleminin $\% 5$ ve yukarısındaki bir düzeyde anlamlı olması; GSYiH ile dış borçlar arasında çift yönlü bir nedensellik olduğunu ifade etmektedir. Ancak aynı nedensellik ilişkileri Tablo-3b ve Tablo-3c'den de anlaşılacağı üzere, GSYiH ile dış borçlar arasında gözlenememektedir.

Tablo-4 Tasarruflar ile dış borçlar arasındaki nedensellikleri belirtmektedir. Tablo-4a'da da tasarruflardan dış borçlara çift yönlü nedensellik ilişkileri tespit edilmektedir. Ancak aynı durum Tablo-4b ve Tablo-4c'den de anlaşlacağı üzere, tasarruflar ile dış borçlar arasında nedensellik ilişkileri gözlenmemektedir. 
Tablo 3. Dönemler itibariyle gayrisafi yurtiçi hâsıla ile dış borçlar arasındaki Granger-nedensellik sınamaları

\begin{tabular}{|c|c|c|}
\hline a)Regresyonlar: 1964-1980 dönemi & FPE & F-değeri \\
\hline$\Delta$ GSYiH $_{t}=\alpha_{11}+$ & $1.3 \mathrm{e}^{-23}$ & \\
\hline$\Delta$ GSYiH $_{t}=\alpha_{12}+\sum_{i=1}^{1} \beta_{11 i} \Delta$ GSYiH $_{t-i}+\sum_{j=1}^{4} \beta_{12 j} \Delta D I S ̧ B O R C_{t-j}+\varepsilon_{12 t}$ & $-1.7 e^{-31}$ & $7.65^{* *}$ \\
\hline$\triangle D I S ̧ B O R C_{t}=\alpha_{21}+$ & $3.6 \mathrm{e}^{-19}$ & \\
\hline$\Delta D I S ̧ B O R C_{t}=\alpha_{22}+\sum_{i=1}^{1} \beta_{21 i} \Delta D I S ̧ B O R C_{t-i}+\sum_{j=1}^{4} \beta_{22 j} \Delta G S Y i H_{t-j}+\varepsilon_{22 t}$ & $-1.7 e^{-28}$ & $4.07^{* * *}$ \\
\hline b)Regresyonlar: 1980-2012 dönemi & FPE & F-değeri \\
\hline$\Delta$ GSYiH $_{t}=\alpha_{11}+\sum_{i=}^{1}$ & $1.2 \mathrm{e}^{-20}$ & \\
\hline$\Delta G S Y i H_{t}=\alpha_{12}+\sum_{i=1}^{1} \beta_{11 i} \Delta G S Y i H_{t-i}+\sum_{j=1}^{4} \beta_{12 j} \Delta D I S B O R C_{t-j}+\varepsilon_{12 t}$ & $9.6 \mathrm{e}^{-13}$ & 1.52 \\
\hline$\Delta D I S ̧ B O R C_{t}=\alpha_{21}+\sum_{i=1}^{3} \beta_{21 i} \Delta D I S ̧ B O R C_{t-i}+\varepsilon_{21 t}$ & $1.9 \mathrm{e}^{-15}$ & \\
\hline$\Delta D I S ̧ B O R C_{t}=\alpha_{22}+\sum_{i=1}^{3} \beta_{21 i} \Delta D I S ̧ B O R C_{t-i}+\sum_{j=1}^{4} \beta_{22 j} \Delta G S Y i H_{t-j}+\varepsilon_{22 t}$ & $3.2 \mathrm{e}^{-10}$ & $3.27^{* * *}$ \\
\hline
\end{tabular}




\section{Zeki KARTAL | Hakan ACAROĞLU}

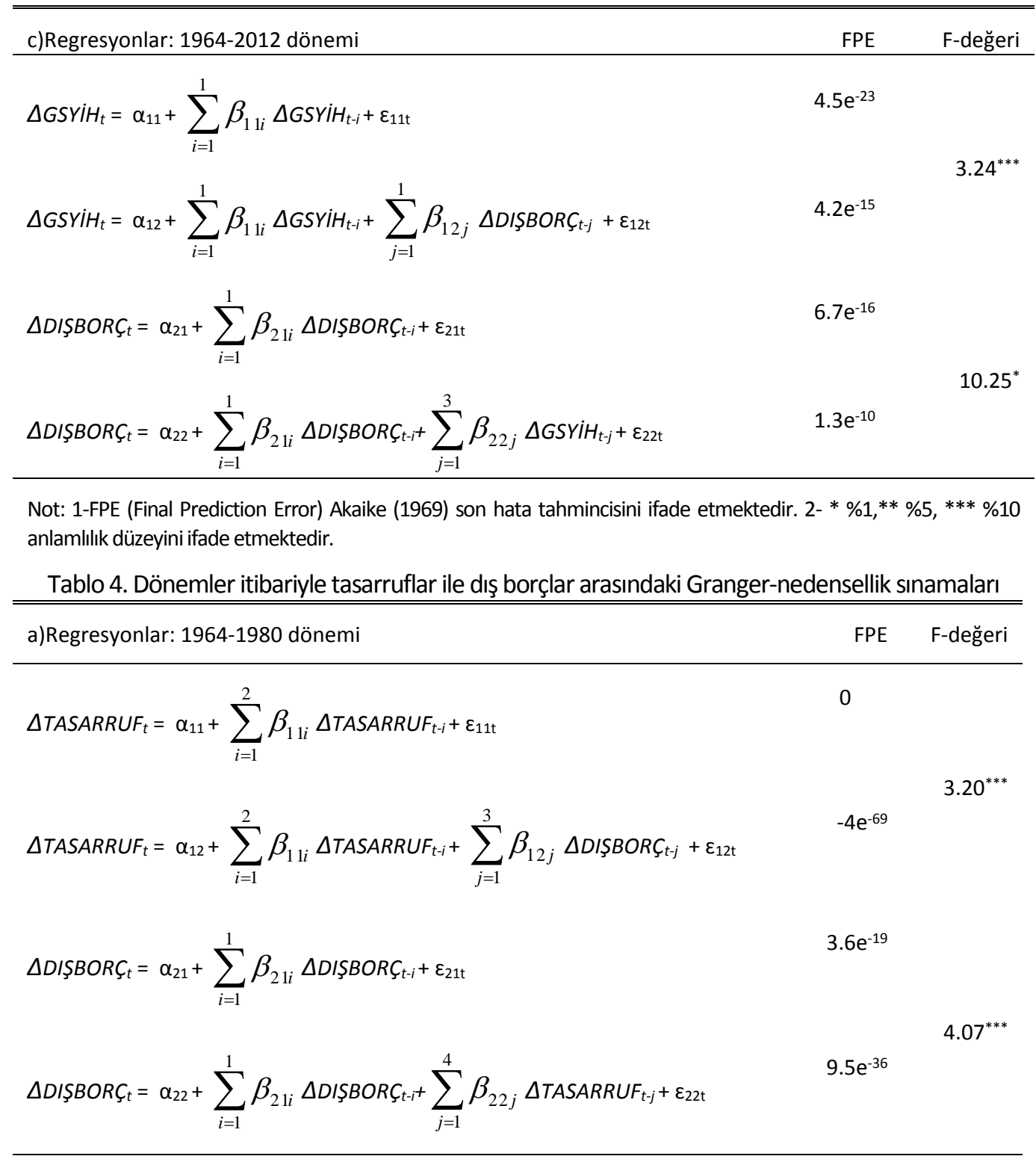




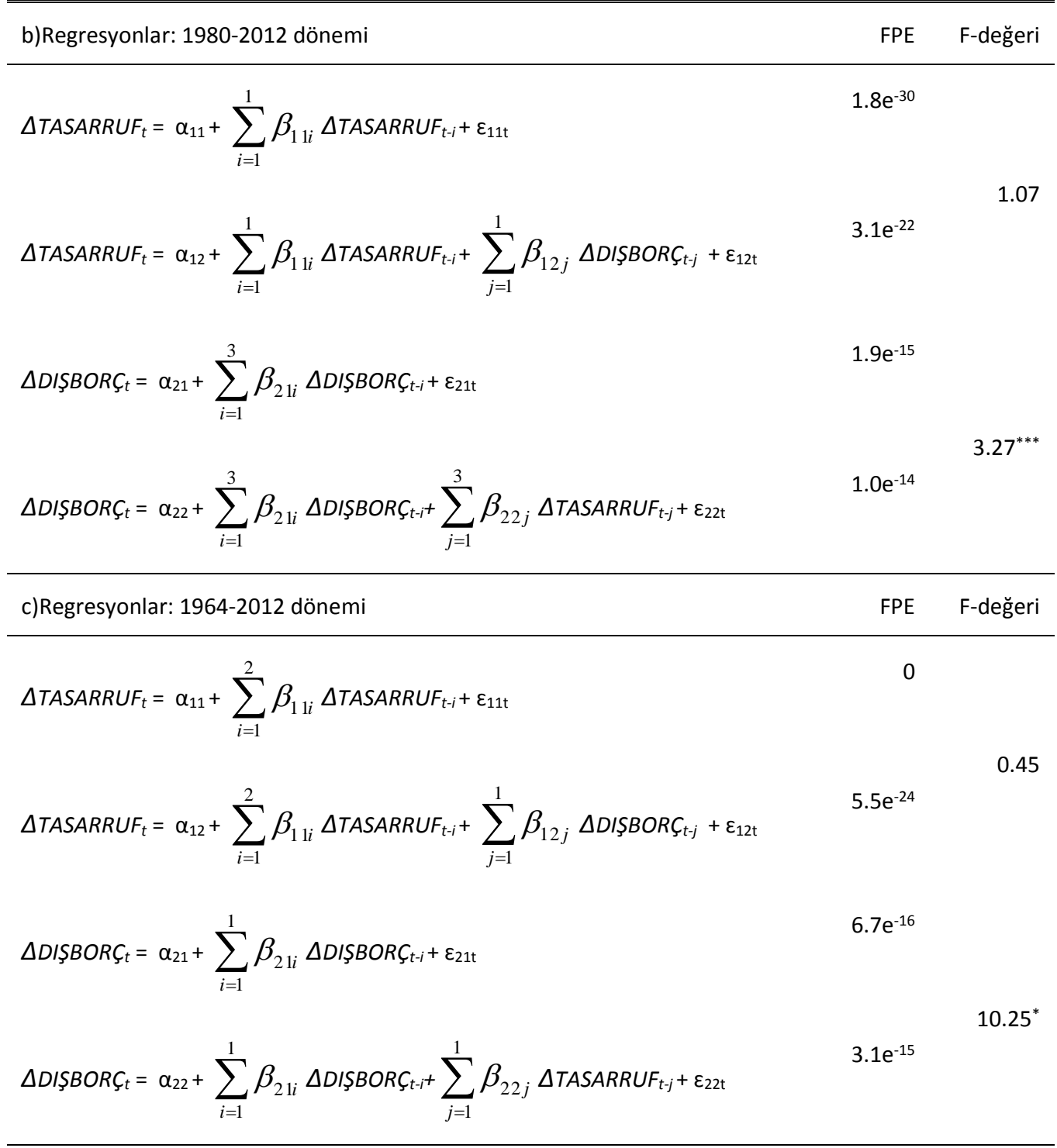

Not: 1-FPE (Final Prediction Error) Akaike (1969) son hata tahmincisini ifade etmektedir. 2- ** \%5 anlamllık düzeyini ifade etmektedir.

\subsection{Ampirik Sonuçların Tartışması}

Bu çalışmada dış borçlar ile GSYiH ve tasarruflar arasında 1964-2012 dönemini kapsayacak şekilde 1980 öncesi ithal ikameci kalkınma stratejisi dönemi ve 1980 sonrası ihracata yönelik kalkınma stratejisi dönemi ayrımında nedensellik ilişkileri incelenmiştir. Sonuçlar Tablo-3 ve Tablo-4'de 


\section{Zeki KARTAL | Hakan ACAROĞLU}

görüldüğü üzere, dış borçlar ile GSYiH ve tasarruflar arasında çift yönlü bir nedensellik bulunduğu ve bu ilişkinin bulunmadığı durumlar fark serilerinin optimal gecikmeli değerlerinden ortaya konulmaktadır.

Ulaşılan bulgulara göre Türkiye'de 1964-1980 döneminde dış borçlar ile GSYiH ve tasarruflar arasında çift yönlü bir nedensellik bulunduğu görülmektedir. Bu ilişkinin arka planında ithal ikameci kalkınma stratejisinin karakteristiğinin yattığı düşünülmektedir. Adı geçen dönemde kamu ve özel teşebbüs iç talebi karşılamak üzere dış kaynakları ağırlıkla sanayi yatırımlarına yönlendirmişler ayrıca alacaklılar da biran önce borcun geri dönmesi için bu konuda fikir birliğinde olmuşlardır.

Buna karşın ihracata yönelik kalkınma stratejisi döneminin 1980'li ve 1990'lı yıllarından 2002'ye kadar birçok iç ve dış krizden dolayı borcu borçla ödeme yolu izlenmiş, uygulanan liberal politikaların doğasına uygun olarak yabancı tüketim malı imkânları artmıştır. Diğer taraftan 2002 yılından itibaren uygulanan mali disiplin, gerçekleşen ekonomik performans, yapısal reformlar, özelleştirmeler ve ihracat artışı borç oranında önemli bir düşüşü beraberinde getirmiştir. 19802012 döneminde ilgili değişkenler arasında bir nedensellik ilişkisinin görülememesinin arka planında yukarıdaki koşulların yattığı düşünülmektedir.

Konuya bir bütün olarak baktığımızda 1964-2012 döneminde ise ilgili değişkenler arasında bir nedensellik ilişkisi görülmemektedir. Bu durumda şu söylenebilir: 1964-1980 döneminde bulunan nedensellik ilişkisini 1980-2012 döneminde bulunamayan nedensellik ilişkisi mas etmektedir.

\section{Sonuç}

Bu çalışmada 1964-2012 dönemi ve Türkiye için, dış borçlar ile GSYiH ve tasarruflar arasındaki ilişkiler araştırımıştır. Bu ilişkiler öncelikle tarihsel perspektiften ele alınmakta sonrasında da meydana gelen teorik çerçeve sınılarınca belirlenen sayısal yöntemlerle incelenmektedir. Bahsi geçen ilişkilerde nedenselliğin yönünü belirlemek için ekonometri zaman serisi tekniklerinden yararlanılmıştır. Türkiye'de 1964-1980 döneminde dış borçlar ile GSYiH ve tasarruflar arasında çift yönlü bir nedensellik ilişkisi gözlemlenmiştir. Bu nedensellik Granger tekniğine dayanarak ortaya konulmaktadır. Belirtilen değişkenler için 1980-2012 ile 1964-2012 dönemlerinde bir nedensellik gözlemlenmemiştir. Araştırma, gelişmekte olan ülkelerde sermaye ithalinin ekonomik büyümeye ve iç tasarrufa yol açabileceği tezini, Türkiye örneğinde ithal ikameci kalkınma stratejisi sürecinde 19641980 dönemine ilişkin desteklerken, ihracata yönelik kalkınma stratejisi döneminde (1980-2012) ise desteklemeyerek dönemsel bir farklılık ortaya koymaktadır. Genel olarak bakıldığında (19642012), Türkiye örneğinde sermaye ithalinin ekonomik büyümeyi ve yurt içi tasarrufu etkin kılmadığı sonucu ortaya çıkmaktadır.

Literatürde bu çalışmaya benzer teknik ve yöntemlerle yapılmış borçlanma, yurtiçi tasarruf ve ekonomik büyüme arasındaki ilişkileri ortaya koyan çalışmalar da mevcuttur. Ancak ortaya konan bulgular noktasında bakış açılarının vermiş olduğu çeşitlilikten de kaynaklı olarak bazı farklııklar söz konusudur. Borçlanmaya iç borçlar cephesinden değinen Çoban ve diğerleri (2008), Türkiye'de 1987-2007 döneminde iç borçlanma ile büyüme arasında bir nedensellik ilişkisi olduğunu belirtmektedirler. Borçlanmaya dış borçlar cephesinden yaklaşan Uysal ve diğerleri (2009), Türkiye'de 
1965-2007 döneminde dış borçların ekonomik büyüme üzerinde olumsuz bir etkiye sahip olduğunu göstermişlerdir. Benzer şekilde, Çiçek ve diğerleri (2010), Türkiye'de borçlanma ve ekonomik büyüme arasındaki ilişkileri incelerlerken, 1990 yılı sonrasında dış borç stokundaki bir artışın GSYiH'da bir azalışa sebep vereceğini belirtmişlerdir. Çöğürcü ve Çoban (2011)'da Türkiye'de 19802009 döneminde dış borçlanmanın ekonomik büyüme üzerinde negatif bir etkisinin olacağını söylemektedirler. Ve buna ek olarak da ekonomik büyümeyi arttırmak için yurtiçi tasarrufların arttırılmasını önermektedirler. Yukarıdaki yaklaşımların karşıtı olarak Umutlu ve diğerleri (2011), Türkiye'de 1990-2008 döneminde dış borçlanmanın büyümeyi pozitif etkilediğini gözlemlemişlerdir. Bizim çalışmamızda da iki farklı dönem (1964-1980, 1980-2012) ayrımına gidilerek ve bu dönemlerin bütünü ele alınarak gelişmekte olan Türkiye'nin sermaye ithali-yurtiçi tasarruf ve ekonomik büyüme ilişkileri incelenmiş. Bu yolla literatüre farkı bir bakış açısı ve zenginlik kazandırılması amaçlanmıştır.

\section{Kaynaklar}

Agarwal, J., P., Dippl, M. ve Glismann, H. H. (1984). Wirkung der Entwicklungshilfe, Köln.

Akaike, H., (1969). Fitting autoregressive models for prediction. Ann. Inst. Stat. Math. 21, 243-247.

Altvater, E. (1993). Zur Ökonomie und Ökologie der Nord-Süd-Beziehungen, in: Nohlen, D. ve Nuscheler, F. (Hrsg.), Handbuch der Dritten Welt, 1. Bd., Grundprobleme, Theorien und Strategien, 3. Aufl., Bonn.

Altvater, E. ve diğerleri (Hrsg.) (1987). Die Armut der Nationen. Handbuch zur Schuldenkrise von Argentinien bis Zaire, Berlin.

Baran, P. A. (1969). Unterdrückung und Fortschritt, 3. Auflage, Frankfurt / Main.

Bender, D. (1992). Entwicklungspolitik, in: Vahlens Kompendium der Wirtschaftstheorie und politik, Bd. 2, 5. Auflage, München.

Bigler, M. (1987). Schuldendienstprobleme von staatlichen Schuldnern in Entwicklungsländern, Beurteilungsansätze und Leitlinien für eine optimal verträglice Auslandsverschuldung. Business International, (1974). Asia / pacific Ltd., 27. November.

Business International, (1974). Asia / pacific Ltd., 27. November.

Chenery, H. B. ve Strout, A. M. (1966). Foreign Assistance and Economic Development, in: The American Economic Review, 56.

Çavdar, T. (1995). Türk İktisadi Düşüncesi, Cumhuriyet Dönemi Türkiye Ansiklopedisi, İletişim yayınları, Cilt 4.

Çiçek, H. ve diğerleri, (2010). Bir Maliye Politikası Aracı Olarak Borçlanma ve Ekonomik Büyüme Illişkisi: Türkiye Örneği (1990-2009). C.Ü. İktisadi ve İdari Bilimler Dergisi, Cilt 11, Sayı 1. 


\section{Zeki KARTAL | Hakan ACAROĞLU}

Çoban, O. ve diğerleri, (2008). Türkiye'de Kamu İç Borçlanmasının Makroekonomik Etkileri. Selçuk Üniversitesi Sosyal Bilimler Enstitüsü Dergisi.

Çögürcü, í. ve Çoban, O. (2011). Dış Borç Ekonomik Büyüme ilişkisi: Türkiye Örneği (1980-2009). KMÜ Sosyal ve Ekonomik Araştırmalar Dergisi, 13 (21): 133-149.

Deutsche Gesellschaft für wirtschaftliche Zusammenarbeit mbH, (1976). Reisebericht Korea, 23. März.

Dünya Kalkınma Göstergeleri (World Development Indicators): Web adresi:

http://data.worldbank.org/country/turkey

Dürr, E. (1977). Wachstumspolitik, Bern-Stuttgart.

Eaton, J. ve Gersovitz, M. (1981). Debt with Potential Repudiation and Empirical Analysis, in: Review of Economic Studies, 68.

Engle, R. F. ve Granger, C. W. J., (1987). Co-Integration and Error Correction: Representation, Estimation, and Testing, Econometrica, Vol. 55, No. 2, s. 251-276.

Elsenhans, H. (1981). Abhengiger Kapitalismus oder bürokratischer Entwicklungsgesellschaft, Frankfurt a.M.

Fischer, B. (1982). Liberalisierung der Finanzmärkte und wirtschaftliches Wachstum in Entwicklungsländern, Tübingen.

Fröbel, F.ve diğerleri, (1977). Neue Internationale Arbeitsteilung, Reinbek.

Gerster, R. (1982). Fallstricke der Verschuldung, Basel.

Glismann, H. H. ve diğerleri, (1987). Weltwirtschaftslehre, Eine Problemorientierte Einführung, 2. Bd., Entwicklungs- und Beschäftigungspolitik, 3. Aufl., Göttingen.

Granger, C.W.J., (1969). Investigating causal relation by econometric and cross-sectional method, Econometrica, 37, 424-438.

Griffin, K. (1974). Rural Development, The Policy Options, in: E.O. Edward (Ed.), Employment in Developing Nations, Edwards.

Guldimann, T. (1975). Lateinamerika, München.

Gürsel, S. (1995). Dış Borçlar, Cumhuriyet Dönemi Türkiye Ansiklopedisi, İletişim yayınları, Cilt 2.

Hsiao, C., (1981). Autoregressive modeling and money income causality detection. J. Mon. Econ. 7, 85-106.

İnsel, A. (1996). Düzen ve Kalkınma Kıskacında Türkiye, Kalkınma Sürecinde Devletin Rolü, Ayrıntı Yayınları, İstanbul. 
İnsel, A. (2003). İktisat İdeolojisinin Eleştirisi, Birikim Yayınları, İstanbul.

Jungfer, J. (1991). Grundbedürfnisstrategie oder Ordnungspolitik als Wege zur Überwindung wirtschaftlicher Unterentwicklung, Bern-Stuttgart.

Keyder, Ç. (1995). iktisadi Gelişmenin Evreleri, Cumhuriyet Dönemi Türkiye Ansiklopedisi, Iletişim Yayınları, Cilt 4.

Knall, B. ve Wagner, N. (1986). Entwicklungsländer und Weltwirtschaft, Darmstadt.

Konrad, A. (1967). Finanzierungsprobleme: Der Zusammenhang von Entwicklungsplan, Budget und Zahlungsbilanz, in: Guth, W. (Hrsg.), Probleme der Wirtschaftspolitik in Entwicklungsländern, Berlin.

Kreye, 0. (1980). Perspektiven des industriellen Wachstums und der sozialen Entwicklung in den Entwicklungsländern, in: Starnberger Studien 4, Strukturveränderungen in der kapitalistischen Weltwirtschaft, Frankfurt.

Leibenstein, H. (1957). Economic Backwardness and Economic Growth, New York.

Mc Kinnon, R. I. (1981). Financial Repression and the Liberalisation Problem within Less Developing Countries, in: Grassman, Sven / Lundberg, Erik (Eds.): The World Economic Order, Past and Prospect, New York.

Nödinger, H. E. (1987). Verschuldung von Entwicklungs-und Schwellenländern, Zürich.

Phillips, P.C.B. ve Perron, P., (1988). Testing for a unit root in time series regression, Biometrika, 75,335-346.

Pollak, Ch. (1991). Industrialisierung, in: P. J. Opitz, Grundprobleme der Entwicklungsländer, München.

Rosenstein-Rodan, P.N. (1961). International Aid For Underdeveloped Countries, in: The Review of Economics and Statistics 43.

Schönherr, S. (1983). Armutsorientierte Entwicklungspolitik, Ansatzpunkte zur Verbindung von Wachstum und Armutsreduzierung durch Förderung kleinbäuerlicher Zielgruppen, Duncker \& Humblot / Berlin.

Sjö, B. (2008). Testing for Unit Roots and Cointegration. Web adresi:

https://www.iei.liu.se/nek/ekonometrisk-teori-7-5-hp-730a07/labbar/1.233753/dfdistab7b.pdf

Tetzlaff, R. (1988). Die Verschuldungskrise der Dritten Welt als Ausdruck der Krise des Weltwirtschaftssystems, in: Altvater, E. ve diğerleri: Soll und Haben, Strategien und Alternativen zur Lösung der Schuldenkrise, Hamburg.

Tezel, Y. S. (1986). Cumhuriyet Döneminin İktisadi Tarihi (1923-1950), Yurt Yayınları 4, Ankara. 


\section{Zeki KARTAL | Hakan ACAROĞLU}

Timmermann, V. (1982). Entwicklungstheorie und Entwicklungspolitik, Göttingen.

Todaro, M.P. (1977). Economic Problems in the Third World, An Introduction to Problems and Policies in a Global Perspective, London.

TÜiK, (2007). İstatistik Göstergeler (Statistical Indicators). 1923-2006.

Tuncer, N. (1995). Tasarruf sorunu, Cumhuriyet Dönemi Türkiye Ansiklopedisi, İletişim yayınları, Cilt 4.

Umutlu ve diğerleri (2011). Maliye Politikası Araçlarından Borçlanma Ve Vergilerin Ekonomik Büyümeye Etkileri. Uludağ Üniversitesi İktisadi ve İdari Bilimler Fakültesi Dergisi, Cilt:XXX, No:1, 75-93.

UNCTAD, (1979). Handbook of International Trade and Development Statistics, New York.

UNIDO, (2013). Industrial Development Report 2013Sustaining Employment Growth: The Role of Manufacturing and Structural Change.

Uysal ve diğerleri (2009). Dış Borçlanma Ve Ekonomik Büyüme ilişkisi: Türkiye Örneği (1965-2007). Atatürk Üniversitesi İktisadi ve İdari Bilimler Dergisi, Cilt:23, Sayı:4.

Yang, H.-Y., (2000). A note on the causal relationship between energy and GDP in Taiwan, Energy Economics 22, 309-317.

Wendt, K.-E.(1988). Die unterentwickelten Länder der Dritten Welt und die Krise des internationalen Finanzsystems, in: Laser, U.H./ Wendt, K.H. (Hg.), Schuldenkrise und Armut in der Dritten Welt, Berlin. 